(International Journal of Agriculture and Wild life Science)
http://dergipark.org.tr/ijaws

Araştırma Makalesi

\title{
İç Anadolu'da İkinci Ürün Döneminde Yem Bezelyesi ve Bazı Tahıl Karışımlarının Farklı Ekim Sıklığında Yaş Ot Verimi ve Bazı Özellikleri
}

\author{
Onur İleri*, Şule Erkovan, Halil ibrahim Erkovan, Ali Koç
}

Eskişehir Osmangazi Üniversitesi, Ziraat Fakültesi, Tarla Bitkileri Bölümü, Eskişehir

Geliş tarihi (Received): 27.04.2020 Kabul tarihi (Accepted): 05.11.2020

\begin{abstract}
Anahtar kelimeler:
İkinci ürün, yem bezelyesi,

karışık ekim, ekim sıkığı

Özet. Çalışmada 2018 ve 2019 yıllarında Eskişehir koşullarında buğday hasadını takiben yapılan ikinci ürün yem bezelyesi üretiminde farklı ekim sıklıkları (80, 100 ve 120 tohum $\mathrm{m}^{-2}$ ) ile farklı oranlarda karışıma dahil edilebilen bazı buğdaygil yem bitkilerinin (\%25 ve \%50 oranlarında yulaf, silajlık mısır ve sudan otu) bitki boyu, yaş ot üretimi, kuru madde oranı ve botanik kompozisyondaki yem bezelyesi oranına etkileri incelenmiştir. Bitki boyu ve baklagil oranı, yıllar ve karışık ekim uygulamaları arasında önemli değişim gösterirken, kuru madde oranı yalnızca karışık ekim uygulamaları arasında önemli değişim göstermiştir. Yaş ot verimi 2018 yılında 2019'a göre daha yüksek olurken, en yüksek yaş ot verimi 100 (2189.84 kg da-1) ve en düşük yaş ot verimi 120 tohum $\mathrm{m}^{2}(1841.68 \mathrm{~kg} \mathrm{da})$ ekim sıklığında tespit edilmiştir. Karışımlar arasında en yüksek yaş ot verimi $3619.02 \mathrm{~kg} \mathrm{da}^{-1}$ ile yem bezelyesine \%50 azaltılmış silajlık mısır karıştııılığında elde edilirken yalın ekimde ( $850.14 \mathrm{~kg} \mathrm{da})$ en düşük olduğu belirlenmiştir. Araştırma sonuçlarına göre ikinci ürün yem bezelyesi üretiminde ekimin 100 tohum $\mathrm{m}^{2}$ sıkığı kullanılarak ve \%50 oranında azaltılmış silajık mısır karıştırılarak yapılmasının verimi önemli ölçüde artırdığını ifade etmek mümkündür.

*Sorumlu yazar

oileri@ogu.edu.tr
\end{abstract}

\section{Fresh Forage Yield and Some Characteristics of Forage Pea-Crop Mix Sowed Using Different Rates in Second Crop Season of Central Anatolia}

\section{Keywords:}

Second crop, forage pea, intercropping, sowing rate

\begin{abstract}
The research was carried out to determine the effects of different sowing rates $(80,100$, 120 seeds $\mathrm{m}^{2}$ ) of forage pea and seed mixtures (oat, silage maize and sudan grass at the rates of $25 \%$ and $50 \%$ ) on plant height of the forage pea, fresh forage yield, dry matter ratio and rate of legume in Eskisehir ecological conditions as second crop production following the wheat harvest during 2018 and 2019. Plant height and rate of legume significantly varied between years and among the sowing rates but dry matter ratio varied only among the seed mixtures significantly. Fresh forage yield that was higher in 2018 , had the highest value at the sowing rate of 100 seeds $\mathrm{m}^{2}\left(21898.4 \mathrm{~kg} \mathrm{ha}^{-1}\right)$ and the lowest at 120 seeds $\mathrm{m}^{2}\left(18416.8 \mathrm{~kg} \mathrm{ha}^{-1}\right)$. The highest fresh forage yield was recorded in the mixture of $50 \%$ silage maize seeds to forage pea ( $\left.36190.2 \mathrm{~kg} \mathrm{ha}^{-1}\right)$ while it was the lowest in conditions of sowing forage pea alone ( $8501.4 \mathrm{~kg} \mathrm{ha})$. Results showed that sowing should be carried out using 100 seeds $\mathrm{m}^{-2}$ of forage pea and a mixture of $50 \%$ reduced silage maize to forage pea to increase the yield.
\end{abstract}




\section{GiRiş}

Ülkemizde hayvansal üretimdeki en büyük sorunlardan birisi kaliteli kaba yem açığı sebebiyle hayvansal üretimde istenilen verim performansının ortaya konulamamasıdır. Mevcut şartlarda bitkisel üretim deseninde ana ürün olarak üretim alanlarının artırılması söz konusu olmadığı için alternatif çözüm arayışları gündeme gelmiştir(Acar ve ark., 2016. Bu konuda bir diğer çözüm yolu da sulu tarım alanlarında tahıl hasadını takiben tek yıllık yem bitkilerinin yetiştiriciliğidir. Nitekim Eskişehir'de bu konuda yapılan çalışmalarda dekara 2 ton civarında yem bezelyesi yaş otu (Dereli, 2015), ve 9 ton civarında silaj mısır üretiminin (ileri ve ark., 2018) yapılabilmektedir. Ekim nöbetine ikinci ürün olarak dahil edilebilen yem bezelyesi (Pisum sativum var. arvense) hayvan beslemede önemli bir kaba yem kaynağı olup (Uzun ve ark., 2012; Özköse, 2017; Tan ve Kadığlu, 2018; Özdemir ve Tamkoç, 2019). baklagil olması nedeniyle de yetiştiriciliğinde yoğun azotlu gübreye intiyaç bulunmamaktadır (Açıkgöz, 2001; Acar ve Mülayim, 2014; Dereli, 2015; Gülümser ve ark., 2017). Son yıllarda yem bezelyesine ilgi artmış olup TÜiK (2019) verilerine göre ülkemizde ekim alanı 4 kat artmıştır.

Kaba yem üretimi amacıyla yapılan yem bitkileri yetiştiriciliğinde bitki sıklığı verimi önemli ölçüde etkilemektedir (Toğay ve ark., 2006; Kavut ve ark., 2016). Genel bir ifade ile bitki sıklığı belirli bir orana kadar arttıkça verimde artış eğilimi ortaya çıkmaktadır (Açıkgöz, 2001; Yılmaz, 2008). Ancak sıklığın fazla olduğu durumlarda bitkiler yatmakta ve çevresel kaynaklardan yeterince yararlanamamaktadır. Bunun sonucu olarak da verim ve kalitede azalış ortaya çıkmaktadır (Egli, 1988). Bu nedenle hem yüksek verimli hem de kaliteli kaba yem üretimi için uygun sıkığın ortaya konulması son derece önemlidir.

Yem bezelyesi üretiminde karşılaşılan problemlerden birisi de yatmadır (Tan ve Serin, 1997; Ay ve ark., 2017; Gülümser ve ark., 2017). Uzun boylu ve zayıf saplara sahip olan yem bezelyesinde yatma nedeniyle bitkide hem hasat zorluğu hem de verim ve kalitede önemli düşüşler ortaya çıkabilmektedir. Bu nedenle yem bezelyesinin sülükleri sayesinde tutunarak yatmadan dik gelişim gösterebilmesi için dik gelişen buğdaygiller ile karışık yetiştirilmektedir. Nitekim baklagil türlerinin buğdaygiller ile karışık yetiştirilmesi sonucu yabancı otların baskılandığı, üretimin arttığı, kaba yemin kalitesi ve enerji içeriğinin daha yüksek olduğu birçok araştıııc tarafından ortaya konulmuş̧tur (Acar ve ark., 2006; Yıldırım ve Özaslan-Parlak, 2016; Ay ve ark., 2017; Gülümser ve ark., 2017; Yavuz, 2017). Ancak uygulanacak karışım oranlarının sonuçları farklı ekolojik şartlarda değişiklik göstereceği için uygun oranların belirlenmesine intiyacı vardır.

Çalışma, İç Anadolu Bölgesi'nin geçit kuşağı iklimini temsil edecek konumda olan Eskişehir'de yürütülmüştür. Farklı sıklıklarda $\left(80,100,120\right.$ tohum $\mathrm{m}^{-2}$ ) ekilen yem bezelyesine ekim ile birlikte \%25 ve \%50 oranlarında yulaf (Avena sativa L.), silajlık mısır (Zea mays L.) ve Sudan otu (Sorghum sudanense) karıştııılarak bitki boyu, yaş ot verimi, kuru madde oranı ve baklagil oranına etkileri incelenmiştir.

\section{MATERYAL VE METOT}

Çalışma, İç Anadolu Bölgesi'nin geçit kuşağı iklimini temsil eden özellikte olan Eskişehir Osmangazi Üniversitesi Ziraat Fakültesi Araştırma ve Deneme Arazisinde 2018 ve 2019 olmak üzere iki yıl süreyle yürütülmüştür.

Deneme alanının 0-20 cm derinliğinden alınan toprak örnekleri Eskişehir Osmangazi Üniversitesi Ziraat Fakültesi Toprak Bilimi ve Bitki Besleme Bölümü Laboratuvarında analiz edilmiştir. Analiz sonuçlarına göre deneme alanı toprakları killi-tın bünye sınıfında, hafif alkali, tuzsuz, potasyumca zengin ve organik madde ile fosfor bakımından fakir olup orta seviyede kireçli yapıda bir özelliğe sahiptir.

Denemenin yürütüldüğü aylara ait ortalama sıcaklık, toplam yağış ve ortalama nem değerleri ile uzun yıllar ortalamaları Çizelge 1'de verilmiştir. Denemenin ilk yılı ikinci yıla göre ikinci ürün yetiştirme döneminde daha fazla yağış almış ve daha sıcak geçmiştir.

Çizelge 1. Denemenin yürütüldüğü 2018 ve 2019 yıllarında ilgili aylara ait iklim verileri.

Table 1. Meteorologic data of the experiment area in the related months of 2018 and 2019.

\begin{tabular}{cccccccccc}
\hline Aylar & \multicolumn{2}{c}{ Aylık Toplam Yağış (mm) } & \multicolumn{3}{c}{ Aylık Ortalama Sıcaklı ( $\left.{ }^{\circ} \mathbf{C}\right)$} & \multicolumn{3}{c}{ Aylık Ortalama Nispi Nem (\%) } \\
\hline & $\mathbf{2 0 1 8}$ & $\mathbf{2 0 1 9}$ & UYO & $\mathbf{2 0 1 8}$ & $\mathbf{2 0 1 9}$ & UYO & $\mathbf{2 0 1 8}$ & $\mathbf{2 0 1 9}$ & UYO \\
\hline Temmuz & 33.8 & 17.4 & 13.03 & 23.0 & 21.8 & 21.9 & 61.6 & 55.7 & 56.0 \\
Ağustos & 11.5 & 2.9 & 15.77 & 23.5 & 22.6 & 21.8 & 57.0 & 55.4 & 56.7 \\
Eylül & 4.6 & 6.6 & 12.98 & 19.1 & 18.8 & 18.0 & 58.8 & 57.7 & 59.3 \\
Ekim & 29.9 & 14.6 & 33.09 & 14.0 & 14.2 & 12.2 & 69.8 & 65.0 & 68.9 \\
\hline Top. Ort. & 79.8 & 41.5 & 74.87 & 19.9 & 19.3 & 18.4 & 61.8 & 58.4 & 60.26 \\
\hline
\end{tabular}


Buğday hasadını takiben ilk yıl 12 Temmuz, ikinci yıl 22 Temmuz tarihlerinde sulanıp tava getirilen toprak pulluk ile işlenmiş ve kültivatör ile hazırlanan tohum yatağına elle ekim yapılmıştır. Bezelyede sıra arası $30 \mathrm{~cm}$ ve $5 \mathrm{~m}$ boyundaki parsellere 5 sıra $\left(7.5 \mathrm{~m}^{2}\right)$ ekim yapılmıştır. Yem bezelyesi ekiminde 80, 100 ve 120 bitki m${ }^{-2}$ olacak şekilde ekim sıklığı ayarlanmıştır. Bu ekimin üzerine parsellere yalın ekiminin \%25 veya 50 'si sıklığında yulaf, silajık mısır ve Sudan otu ekimi yapılmıştır. Bu amaçla yulafta 18 kg da (Başaran ve ark., 2018), silajık mısır için 10.000 bitki da ${ }^{-1}$ (Turgut ve ark., 2005) ve sudan otu için $2 \mathrm{~kg} \mathrm{da}^{-1}$ (Açıkgöz, 2001) ekim sıklıkları kullanılarak ekim yapılmıştır. Gübre uygulaması yapılmamış, ekimin ardından yağmurlama sistemi ile çıkış sulaması yapılmıştır. Takip eden sulama uygulamaları bitkilerin su ihtiyacı göz önüne alınarak yapılmıştır.

Hasat zamanı yem bezelyesine göre belirlenmiş ve Uzun ve ark. (2012)'nin belirttiği şekilde alt baklaların şekillendiği dönemde yapılmıştır. Hasat öncesi parsellerde rastgele seçilen 10 yem bezelyesinde toprak seviyesinden boy ölçümü yapılarak ortalama boy uzunluğu belirlenmiştir. Hasat, ilk yıl 15 Ekim ve ikinci yıl 4 Ekim tarihlerinde parselin en dış sıraları ve başlangıç ile sonundan 0.5 metrelik kısım kenar tesiri olarak atıldıktan sonra ortadaki 3 sıra biçilerek yapılmıştır. Biçilen örnekler yaş şekilde tartılarak yaş ot verimleri, sonrasında baklagil ve buğdaygil türleri ayrılarak tartılmak suretiyle ağırlığa göre türlerin kompozisyondaki payları belirlenmiş ve ardından örnekler $70^{\circ} \mathrm{C}$ 'de sabit ağırlığa gelene kadar (Cook and Stubbendieck, 1986) kurutularak da kuru madde oranları hesaplanmıştır.

Veriler SAS 9.3 programında tesadüf blokları deneme deseninde bölünmüş parseller düzenlemesine göre varyans analizine tabi tutulmuş ve ortalamalar TUKEY çoklu karşılaştırma testi ile karşılaştııılmıştır (SAS Institute, 2011). Baklagil oranı ile ilgili varyans analizinde saf ekim bezelye verileri hariç tutulmuştur.

\section{BULGULAR VE TARTIŞMA}

Bezelyeye ait ortalama bitki boyu $123.15 \mathrm{~cm}$ olmuş ve bitki boyu ile ilgili olarak yıllar ve ekim şekillerinin etkisi istatistiksel olarak önemli $(P \leq 0.01)$ bulunmuştur. Yine yıl x ekim sıklığı x karışım oranı interaksiyonu da önemli bulunmuştur (Çizelge 2). Çalışmanın ilk yılında $145.36 \mathrm{~cm}$ olan bitki boyu ikinci yıl daha kısa $(104.94 \mathrm{~cm})$ ölçülmüştür. Ekim sıklıkları arasındaki boy farkı istatistiksel anlamda önemsiz olurken karışık ekim uygulamaları arasında en uzun boy $140.18 \mathrm{~cm}$ ile \%50 silajlık mısır uygulamasından elde edilmiştir. Yalın ekilen bezelyeler en kısa boya $(114.78 \mathrm{~cm})$ sahip olmuştur. İlk yılda bezelyeye ait bitki boyları \%50 silaj mısır karışımı parsellerinde kaydedilen bitki boyuna benzer olurken, ikinci yılda \%50 silaj mısır karıştırılan parsellerden elde edilen değerler daha yüksek olmuştur. Yine ilk yılda ekim sıklıklarının bitki boyu üzerinde etkisi olmazken, ikinci yılda genel olarak 80 tohum $\mathrm{m}^{-2}$ ekimleri daha yüksek boya sahip olmuştur (Şekil 1). Ortaya çıkan bu durum yıl x ekim sıklığı x karışım oranı interaksiyonunun önemli çıkmasında etkili olmuştur.

Yaş ot verimi, ele alınan faktörlerin tüm seviyeleri arasında istatistiksel olarak önemli farklılık $(P \leq 0.01)$ göstermiş, ortalama yaş ot verimi $1998.86 \mathrm{~kg} \mathrm{da}^{-1}$ olarak belirlenmiştir. Varyans analizi sonucunda 3'lü interaksiyon önemli bulunmuştur (Çizelge 2). Çalışmanın ikinci yılında yaş ot verimi $2714.82 \mathrm{~kg} \mathrm{da}^{-1}$ ile ilk yıla göre (1282.91 kg da) oldukça yüksek bulunurken, ekim sıklıkları arasında $\mathrm{m}^{2 \prime}$ de 100 tohum uygulamasında en yüksek (2189.84 kg da) yaş ot verimi tespit edilmiştir. Çalışmada ele alınan karışık ekim uygulamalarında elde edilen yaş ot verimi, yalın ekime göre $\left(850.14 \mathrm{~kg} \mathrm{da}^{-1}\right)$ daha yüksek bulunurken, karışık ekimler arasında \%50 silajık mısırda en yüksek (3619.02 kg da) ve \%50 yulafta ise en düşük (1262.12 kg da) olarak kaydedilmiştir. Yıllara göre ekim sıklığı ve karışım oranına ait yaş ot verimleri parseller arasında belirgin farklar sergilemiştir (Şekil 2) Ancak her iki yılda da en yüksek verim \%50 silaj mısır ile $\mathrm{m}^{2 \prime}$ ye 100 bezelye tohumu atılan parsellerde kaydedilmiştir.

Ortalama \%21.85 olan kuru madde oranı üzerine yıllar ile ekim sıklığının etkisi istatistiksel olarak önemli olmazken, ekim şekli ve 3'lü interaksiyon önemli olmuştur. En yüksek kuru madde oranı \%24.97 ile \%50 Sudan otu karışımından elde edilmiş ve bu uygulamayı, \%25 Sudan otu karışımından elde edilen kuru madde oranı (\%24.51) takip etmiş ancak istatistiksel olarak aynı grupta yer almıştır (Çizelge 2). En düşük kuru madde oranı ise \%50 silajık mısır karışımında (\%19.87) belirlenmiştir. Denemenin ilk yılında farklı ekim sıklığı ve karışımlarında $\mathrm{m}^{2 \prime}$ ye 100 ve 120 tohum ekilen parsellerde daha yüksek kuru madde oranı kaydedilirken, ikinci yılda fark gözlenmemiştir (Şekil 3). Yıllara göre ekim şekli ve sıklığında kuru madde oranı yönünden görülen farklılıklar 3'lü interaksiyonun önemli çıkmasında etkili olmuştur.

Ortalama \%58.92 olan bezelye oranı ilk yılda ikinci yıla göre daha yüksek olmuştur $(P \leq 0.01)$. Ekim sıklığının bezelye oranı üzerine etkisi istatistiki olarak önemli olmazken, yulaf parsellerinde diğer karışım parsellerine göre daha yüksek bezelye oranı kaydedilmiştir (Çizelge 2). illk yılda karışık ekimlerde buğdaygil tür ve sıklığının üretilen otta bezelye oranı üzerine etkisi önemli olmazken, ikinci yılda silaj mısır ve Sudan otu sıklığı arttıkça üretilen otta bezelye oranı azalmıştır (Şekil 4). Bu durum üretilen otta bezelye oranı üzerine yıl x ekim sıklığının etkisinin önemli çıkmasına sebep olmuştur. 
Çizelge 2. Ele alınan parametrelere ait ortalamalar ve varyans analizi sonuçları.

Table 2. Means and the results of ANOVA related to investigated parameters.

\begin{tabular}{|c|c|c|c|c|}
\hline & $\begin{array}{l}\text { Bitki Boyu } \\
(\mathrm{cm})\end{array}$ & $\begin{array}{l}\text { Yaş ot verimi } \\
\text { (kg da) }\end{array}$ & $\begin{array}{c}\text { Kuru madde oranı } \\
(\%)\end{array}$ & $\begin{array}{c}\text { Baklagil oran } \\
(\%)\end{array}$ \\
\hline \multicolumn{5}{|l|}{ Yıl (Y) } \\
\hline 2018 & $145.36 \mathrm{a}$ & $1282.91 \mathrm{~b}$ & 22.07 & $74.61 \mathrm{a}$ \\
\hline 2019 & $104.94 \mathrm{~b}$ & $2714.82 \mathrm{a}$ & 21.63 & $43.24 \mathrm{~b}$ \\
\hline \multicolumn{5}{|l|}{ Ekim sıklığı (E) } \\
\hline 80 tohum $\mathrm{m}^{2}$ & 127.27 & $1965.06 \mathrm{~b}$ & 21.62 & 55.95 \\
\hline 120 tohum $\mathrm{m}^{2}$ & 121.84 & $2189.84 a$ & 21.81 & 60.89 \\
\hline 140 tohum $\mathrm{m}^{2}$ & 126.38 & $1841.68 \mathrm{c}$ & 22.05 & 60.29 \\
\hline \multicolumn{5}{|l|}{ Karışımlar (K) } \\
\hline Yalın Ekim & $114.78 \mathrm{c}$ & $850.14 \mathrm{f}$ & $20.31 \mathrm{~b}$ & - \\
\hline$\% 25$ Yulaf & $124.87 \mathrm{bc}$ & $1567.57 \mathrm{~d}$ & $21.09 \mathrm{~b}$ & $64.57 \mathrm{a}$ \\
\hline$\% 50$ Yulaf & 115.63 c & $1262.12 \mathrm{e}$ & $20.96 b$ & $64.48 \mathrm{a}$ \\
\hline \%25 Mısır & 119.67 bc & $2462.03 \mathrm{~b}$ & $21.24 b$ & $50.60 \mathrm{~b}$ \\
\hline \%50 Mısır & 140.18 a & $3619.02 \mathrm{a}$ & $19.87 \mathrm{~b}$ & $41.64 \mathrm{~b}$ \\
\hline$\% 25$ Sudan otu & $130.38 \mathrm{~b}$ & 2036.36 c & $24.51 \mathrm{a}$ & $48.56 \mathrm{~b}$ \\
\hline \%50 Sudan otu & $130.55 \mathrm{~b}$ & $2194.79 c$ & $24.97 \mathrm{a}$ & $42.62 \mathrm{~b}$ \\
\hline Ortalama & 125.15 & 1998.86 & 21.85 & 58.92 \\
\hline Y & $* *$ & $\star \star$ & öd & $\star *$ \\
\hline $\mathrm{E}$ & öd & ** & öd & öd \\
\hline K & $* *$ & ** & $* *$ & $\star *$ \\
\hline$Y \times E$ & öd & ** & * & öd \\
\hline $\mathrm{Y} \times \mathrm{K}$ & * & ** & ** & $\star \star$ \\
\hline $\mathrm{T} \times \mathrm{K}$ & $* *$ & $* *$ & * & öd \\
\hline$Y \times E \times K$ & ** & ** & ** & öd \\
\hline
\end{tabular}

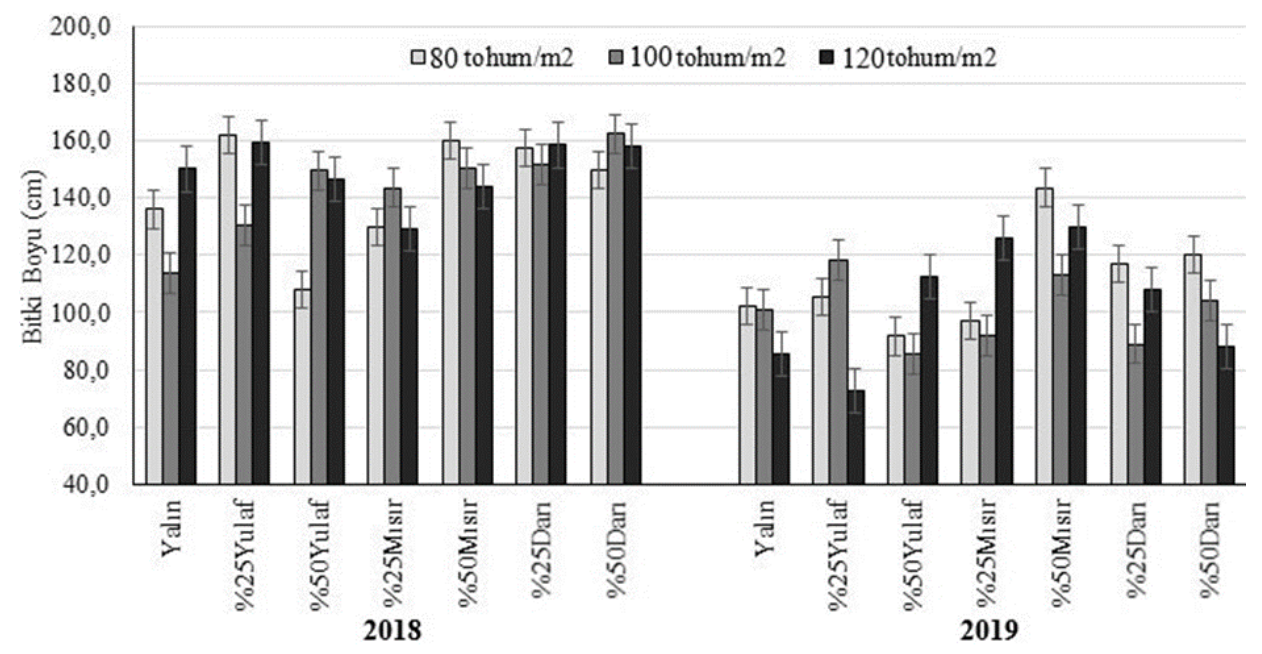

Şekil 1. Yem bezelyesinde bitki boyunun ekim sıklığı, karışım şekli ve yıllara göre değişimi.

Figure 1. Variation in plant height of forage pea in terms of sowing ratio, mix type and years.

Bezelye sınırsız büyüme özelliği olan bir bitkidir (Biddle, 2017) ve en iyi gelişmeyi $15-21^{\circ} \mathrm{C}$ sıcaklık aralığında gösterir (Sattell ve ark., 1998). Denemenin ilk yılında serin iklimin hakim olduğu ekim ayında hasadın daha geç yapılmış olması sınırsız büyüme özelliğindeki yem bezelyesinde daha fazla boy uzamasına sebep olmuştur. Bu nedenle ilk yıl bitki boyu daha uzun olmuştur. Işığa rekabet belirli bir sıklığa kadar bitkilerde boy artışına sebep olabilmektedir (Singh ve ark., 2001; Toğay ve ark., 2006). Ancak denemede ele alınan bitki sıklıklarının birbirine yakın olması ışığa rekabeti tetikleyecek yoğunlukta olmaması nedeniyle ekim sıklıkları arasında bitki boyu yönünden farklılık ortaya çıkmamıştır. Benzer sonuçlar Seviş-Demir (2016) ve Ibrahim ve ark. (2019) gibi araştırııılar tarafından da kaydedilmiştir. Ele alınan karışım şekillerinde \%50 silaj mısır ile birlikte ekilen bitkilerde daha uzun boy elde edilmiştir. Bu durum iri habitüslü ve yüksek boylu olan mısır bitkisinin artan sıklığının sonucu bezelyenin ışığa ulaşmak için daha fazla boy uzatması nedeniyle gerçekleşmiş olabilir. Yıllar arasında ekim sıklığı ve karışım şekillerine bağlı olarak ortaya çıkan farklılıklar yıllar arasında iklimin farklı seyretmesinden 
kaynaklanmıştır. İklim seyrinin bitkilerde gelişmeyi farklı şekilde etkilediğine vurgu yapan Tan ve Kadığlu (2018)'nun bulguları da bu ifadeyi desteklemektedir.

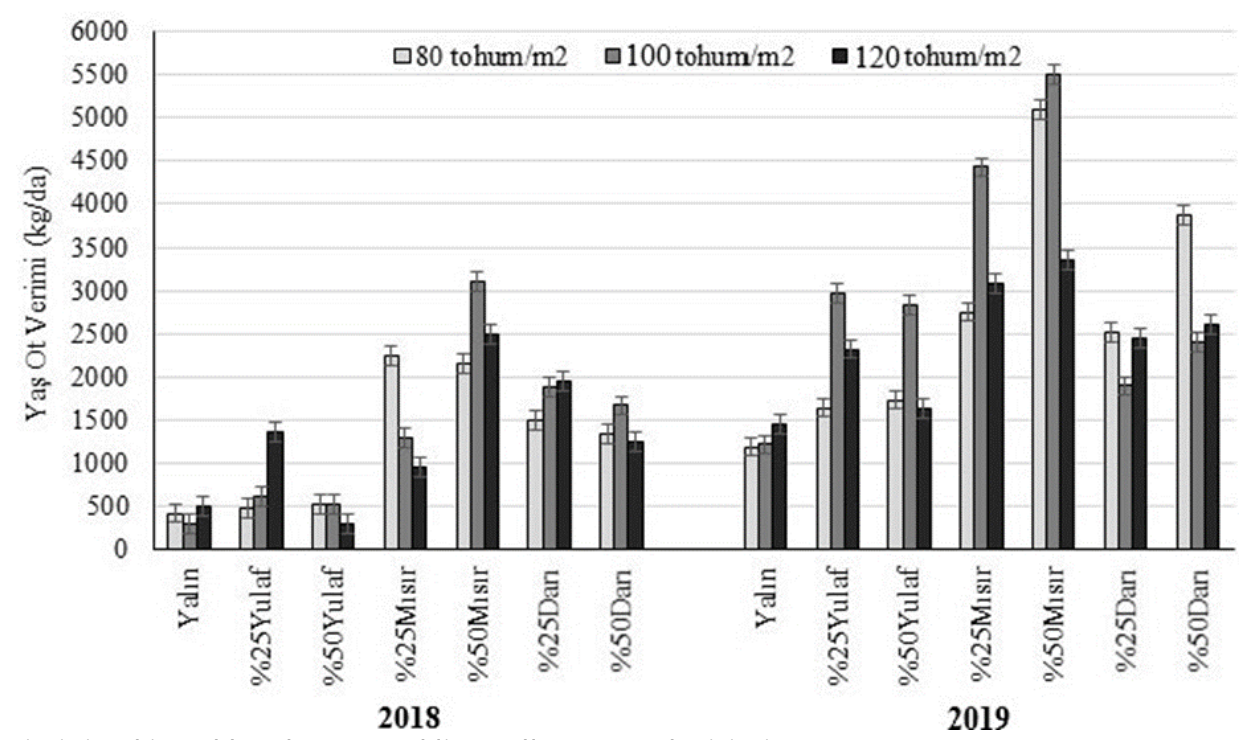

Şekil 2. Yaş ot veriminin ekim sıklığı, karışım şekli ve yıllara göre değişimi.

Figure 2. Variation of fresh forage yield in terms of sowing ratio, mix type and years.

Yem bezelyesinin yaş ot verimi çevresel şartlardan önemli şekilde etkilenmekle birlikte serin iklim bitkisi özelliğine sahip olması (Açıkgöz, 2001) nedeniyle özellikle ikinci ürün şartlarında yüksek sıcaklıklarla birlikte veriminde önemli ölçüde düşüş meydana gelmesi beklenmektedir. Çalışmanın yürütüldüğü aylarda sıcaklığın yüksek olması nedeniyle 2018 yılı yaş ot verimleri 2019 yılından oldukça düşük kalmıştır. Nitekim serinleyen havalarla birlikte bitkiler iyi geliştiği ve geç biçildiği için bu yılda bezelyeler daha uzun boylu olmuştur (Çizelge 2).

Bitki sıklığındaki artış verimi önemli ölçüde etkilemektedir. Genel olarak sıklıktaki artış belirli bir seviyeye kadar verimi artırmakta ancak sonrasında verimde düşüşe neden olmaktadır (Yılmaz, 2008; Spies ve ark., 2010). Ele alınan ekim sıklıkları içerisinde en yüksek yaş ot verimi Uzun (1997) ve Yavuz (2005)'un kaydettiği gibi 100 tohum m² ekim sıklığından alınmıştır

Karışık ekimlerde en yüksek toplam yaş ot veriminin \%50 silaj mısır karışımından elde edilmesi beklenen bir durumdur. Zira mısır iri habitüslü bir bitki olup birim alanda bol kütle üretme yeteneğine sahiptir. Nitekim mısır ile yapılan karışım çalışmalarında (Erdal ve ark., 2016; Htet and Soomro, 2016) artan mısır sıklığına bağlı olarak birim alandan verimin arttığı rapor edilmiştir. Bir diğer sıcak mevsim bitkisi olan Sudan otu karışımlarında yüksek verimin ortaya çıkmamasında Sudan otundaki allelopatik bileşiklerin (Weston, 1989) bezelyeyi baskı altına almış olmasından kaynaklanabilir. Nitekim Sudan otu karışımlarında baklagil oranının düşük olması bu ifadeyi desteklemektedir. Yıllar arasında iklimin seyrinden kaynaklanan farklılıklara bağlı olarak ekim sıklığı ve karışım şekline göre verim performansı değişse de her iki yılda da en yüksek verim $\mathrm{m}^{2 \prime}$ ye 100 bezelye tohumu ve \%50 sıklıkta silaj mısır ekilen parsellerden elde edilmiştir.

Kuru madde oranı bitkilerde gelişmenin ilerlemesiyle artmakta ve özellikle kurak ve yarı kurak iklimlerde yağış durumundan önemli ölçüde etkilenmektedir (Gibson, 2009; Yavuz, 2017). Çalışmanın ikinci ürün koşullarında sulu şartlarda yürütülmesi bitkilerde yıllara bağlı olgunlaşma farkı ve dolayısıyla kuru madde oranında önemli bir farklıık ortaya çıkmamasına sebep olmuştur. Ekim sıklıkları arasında da kuru madde oranı bakımından önemli bir fark görülmezken ekim sıklıkları ve karışık ekim uygulamalarının kuru madde oranına etkisi yıllara göre farklıık göstermiş̧ir (Şekil 3). Karışık ekim uygulamaları arasında özellikle Sudan otu ile yem bezelyesi karışımında kuru madde oranının daha yüksek olduğu tespit edilmiştir. Sudan otunun allelopatik içeriği nedeniyle yem bezelyesini strese sokarak kuru madde oranında artışa sebep olması muhtemeldir. Çünkü allelopatik stres şartları altında bitkilerde verimi azalmakla birlikte kuru madde oranı artış göstermektedir (Khaliq ve ark., 2013; Singh, 2015). 


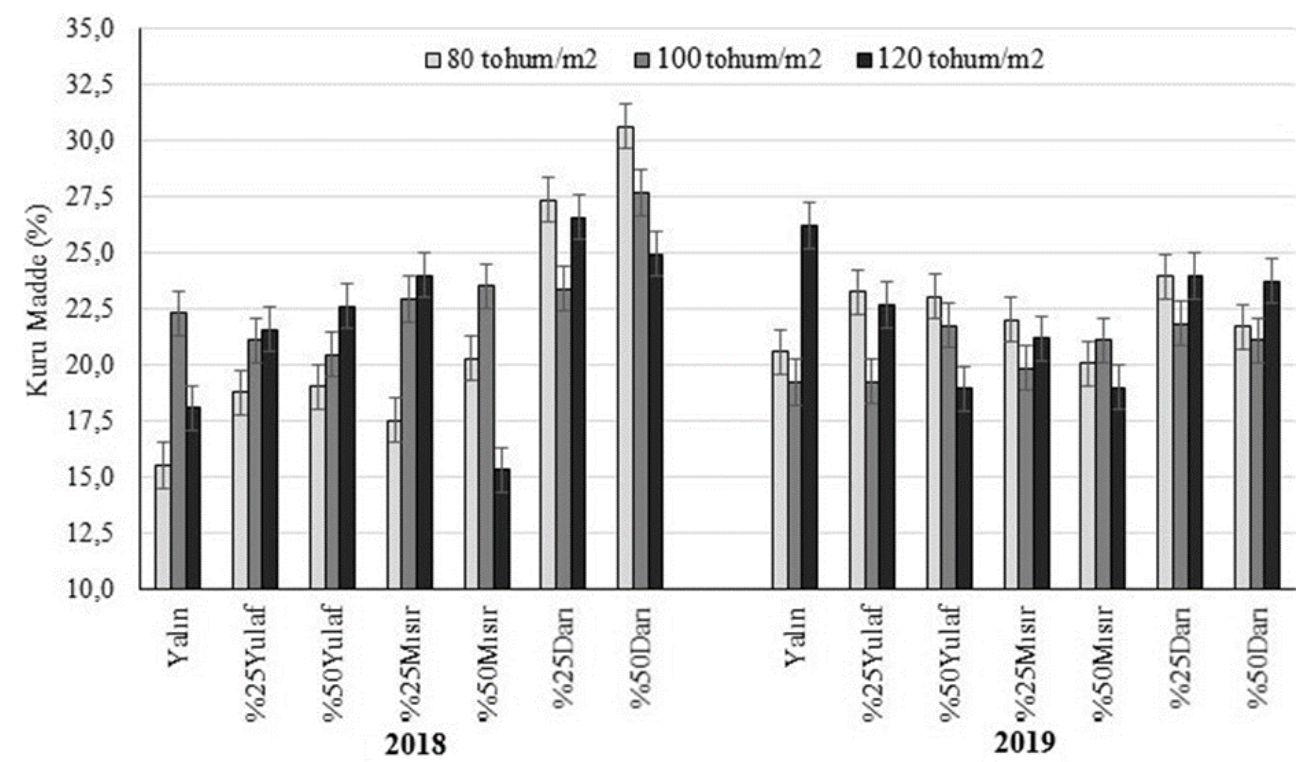

Şekil 3. Kuru madde oranının ekim sıklığı, karışım şekli ve yıllara göre değişimi.

Figure 3. Variation of dry matter ratio in terms of sowing ratio, mix type and years.

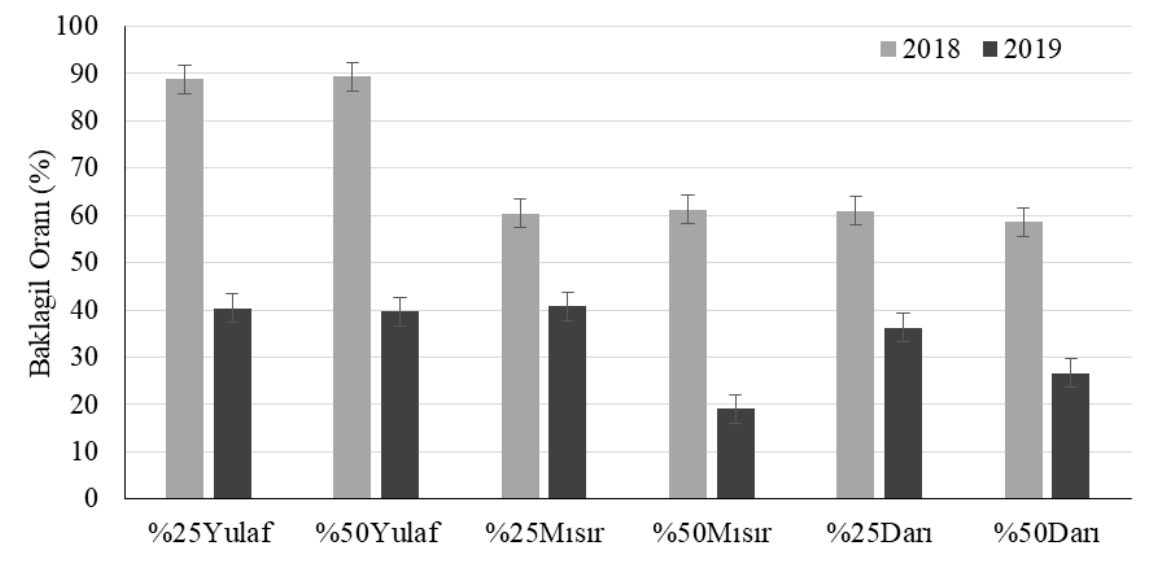

Şekil 4. Karışımlara ait baklagil oranının karışım oranı ve yıllara göre değiş̧imi.

Figure 4. Variation of legume ratio in terms of mix type and years.

Üretilen toplam otta baklagil oranı, çalışmanın ikinci yılında belirgin bir düşüş göstermiştir. Bu durum muhtemelen ilk yılda karışıma alınan buğdaygillerin de fide döneminde zarar görmesinden kaynaklanmış olabilir. Zira ilk yılda çıkış döneminde gözlenen yüksek sıcaklıklar fide ölümüne neden olmuştur (Koç, Erkovan, İleri, kişisel gözlem). Denemenin ikinci yılında ise geciken ana ürün hasadı ve ekim yapılan dönemde havaların nispeten kapalı ve serin gitmesi nedeniyle buğdaygil türleri normal sıklıklarını korumuş ve daha iyi gelişme göstererek verime katkıları artmıştır. Nitekim yapılan çalışmaların büyük çoğunluğunda karışık ekimlerde buğdaygil yoğunluğu arttıkça baklagillerin oranının düştüğü kaydedilmiştir (Yıldırım ve Özaslan-Parlak, 2016; Özaslan-Parlak ve Göçmen, 2017). Benzer sonuçlar bu çalışmanın ikinci yılında da kaydedilmiştir. Karışık ekimlerde sıcak iklim tahıllarının yer aldığı karışımlarda buğdaygil sıklığı artııça baklagil oranı azalırken, serin iklim tahılı olan yulafta bu durum ortaya çıkmamışırı (Şekil 4). Yulafın seyrek ekimlerde daha fazla kardeşlenerek birim alandaki sap sayısını artırması ve buna bağlı olarak üretime katkısını artırmasından kaynaklanabilir.

\section{SONUÇ}

Sonuç olarak elde edilen veriler bir bütün olarak değerlendirildiğinde; Eskişehir ve benzer ekolojik koşullarda ikinci ürün yem bitkisi yetiştirerek kaba yem açığından kaynaklanan sorunun hafifletilebilmesi mümkündür. Bu amaçla buğday veya arpa hasadını takiben kalan sürede silajlık mısır yetiştirilebileceği gibi (ileri ve ark., 2018) yem bezelyesi ile silaj mısır karışımı da yetiştirilebilir. Tohumluk miktarı bakımından $\mathrm{m}^{2 \prime}$ ye 100 yem bezelyesi tohumu ile 5 mısır tohumu gelecek şekilde ekim yapılabilir. Bu sayede sonbahar soğuklarının erken bastırması durumunda silaj mısırın hasat olgunluğuna gelememesi gibi bir risk olduğu için daha güvenli bir kaba yem kaynağı elde edilmiş 
olacaktır. Elde edilen sonuçlara göre Sudan otu ve yulaf ile bezelye karışımı yetiştirmek silaj mısır ile yetiştirmeye göre dezavantajlı gözükmektedir. Ekimler normal bezelye sıklı̆ında yapıldıktan sonra üstüne \%50 silaj mısır ilave edilerek yapılabilir. Bunula birlikte yörede sürdürülebilir ikinci ürün tarımı açısından tür, çeşit bazında yeni karışım ile sulama ve gübreleme gibi denemelere intiyaç bulunmaktadır.

\section{ÇIKAR ÇATIŞMASI}

Yazarlar arasında herhangi bir çıkar çatışması yoktur.

\section{YAZAR KATKISI}

Yazarlar makaleye ekip çalışması ile eşit şekilde katkıda bulunmuştur.

\section{TEŞEKKÜR}

Eskişehir Osmangazi Üniversitesi Ziraat Fakültesi'ne çalışmanın yürütülmesi için gerekli olan arazi ve imkanların sağlanması sebebiyle teşekkür ederiz.

\section{KAYNAKLAR}

Acar, R., \& Mülayim, M. 2014. Konyada bazı yem bitkilerinin doğrudan anıza ekim yöntemiyle ikinci ürün olarak yetiştirilmesi. Bahri Dağdaş Bitkisel Araştırma Dergisi, 1(1-2), 20-25.

Acar, R., Ozkose, A., Isik, S., \& Acar, B. (2016). Yield performance of forage kochia with different stem color under water shortage Konya province of Turkey. International Journal of Agriculture and Economic Development, 4(1), 21.

Acar, Z., Önal, Ö., Ayan, I., Mut, H., \& Başaran, U. (2006). Yem bitkilerinde karışık ekim sistemleri. Anadolu Tarım Bilimleri Dergisi, 21(3), 379-386.

Açıkgöz, E. (2001). Yem Bitkileri (3. Baskı). Uludağ Üniversitesi Güçlendirme Vakfı Yayın No: 182, Bursa.

Ay, U., Alıın, M., \& Şen, C. (2017). Kırklareli koşullarında yem bezelyesi (Pisum arvense L.)-buğday'ın (Triticum aestivum L.) farklı karışım oranları ve biçim zamanlarııın ot verimi ve kalitesine etkisi. Tekirdağ Ziraat Fakültesi Dergisi, 14(3), 80-85.

Başaran, U., Gülümser, E., Mut, H., \& Çopur Doğrusöz, M. (2018). Mürdümük + tahıl karışımlarının silaj verimi ve kalitesinin belirlenmesi. Türk Tarım-Gıda Bilim ve Teknoloji Dergisi, 6(9), 1237-1242.

Biddle, A. J. (2017). Peas and Beans. CABI, Publ., Inc., London.

Cook C. W., \& Stubbendieck, J. (1986). Range Research: Basic Problems and Techniques. Society for Range Management, Publish number: 632, Colorado.

Dereli, D. N. (2015). Eskişehir ekolojisinde bazı baklagil yem bitkilerinin ikinci ürün olarak yetiştirilebilirliği. Yüksek Lisans Tezi, Eskişehir Osmangazi Üniversitesi, Fen Bilimleri Enstitüsü, Eskişehir.

Egli, D. B. (1988). Plant density and soybean yield. Crop Science, 28(6), 977-981.

Erdal, S., Pamukcu, M., Curek, M., Kocaturk, M., \& Dogu, O. Y. (2016). Silage yield and quality of row intercropped maize and soybean in a crop rotation following winter wheat. Archives of Agronomy and Soil Science, 62(11), 1487-1495.

Gibson, D. J. (2009). Grasses and Grassland Ecology, Oxford University Press.

Gülümser, E., Mut, H., Doğrusöz, M. Ç., \& Başaran, U. (2017). Baklagil yem bitkisi tahıl karışımların ot kalitesi üzerinde tohum oranlarının etkisi. Selçuk Tarım ve Gıda Bilimleri Dergisi, 31(3), 43-51.

Htet, M. N. S., \& Soomro, R. N. (2016). Effect of different planting structure of maize and soybean intercropping on fodder production and silage quality. Current Agriculture Research Journal, 4(2), 125-130.

Ibrahim, D. M., Mohamed, S. J., \& Ahmed, S. M. (2019). Effects of plant density on seed yield and it's components of two pea (Pisum sativum L.) cultivars under rainfed condition in Sulaimani province. Journal of Kerbala for Agricultural Sciences, 6(1), 36-48.

Ileri, O., Budaklı-Çarpıcı, E., Erbeyi, B., Avcı, S., \& Koç, A. (2018). Effect of sowing methods on silage yield and quality of some corn cultivars grown in second crop season under irrigated condition of Central Anatolia, Turkey. Turkish Journal of Field Crops, 23(1), 72-79. 
Ileri ve ark., İç Anadolu'da İkinci Ürün Döneminde Yem Bezelyesi ve Bazı Tahıl Karışımlarının Farklı Ekim Sıklığında Yaş Ot Verimi ve Bazı Özellikleri

Kavut, Y. T., Çelen, A. E., Çıbık, Ş. E., \& Urtekin, M. A. (2016). Ege Bölgesi koşullarında farklı sıra arası mesafelerinde yetiştirilen bazı yem bezelyesi (Pisum arvense L.) çeşitlerinin verim ve diğer bazı özellikleri üzerine bir araştırma. Tarla Bitkileri Merkez Araştırma Enstitüsü Dergisi, 25(Özel sayı -2), 225-229.

Khaliq, A., Matloob, A., Mahmood, S., \& Wahid, A. (2013). Seed pre-treatments help improve maize performance under sorghum allelopathic stress. Journal of Crop Improvement, 27(5), 586-605.

Özaslan-Parlak, A. \& Göçmen, N. (2017). Yem bezelyesi ile arpa, yulaf ve tritikale karışım oranlarının belirlenmesi. Çanakkale Onsekiz Mart Üniversitesi Ziraat Fakültesi Dergisi, 5(1), 119-124.

Özdemir, B., \& Tamkoç, A. (2019). İkinci ürün için uygun olan yem bezelyesi hatlarının belirlenmesi. Bahri Dağdaş Bitkisel Araştırma Dergisi, 8(2), 299-305.

Özköse, A. (2017). Farklı ekim derinliklerinin yem bezelyesinin verim ve bazı verim özellikleri üzerine etkileri. Sakarya Üniversitesi Fen Bilimleri Enstitüsü Dergisi, 21(6), 1188-1200.

SAS Institute Inc. (2011). Base SAS 9.3 Procedures Guide, NC.

Sattell, R. D., Hemphill, D., \& McGrath, D. (1998). Field pea (Pisum sativum L. or Pisum sativum L. ssp. arvense (L.) poir.). Oregon State University Extension Service, EM 8698, Oregon.

Seviş Demir, R. (2016). Bazı bezelye (Pisum sativum L.) çeşitlerinde farklı bitki sıklıklarının ve gübreleme uygulamasının verim ve verim unsurlarına etkisi. Yüksek Lisans Tezi, Dicle Üniversitesi, Fen Bilimleri Enstitüsü, Diyarbakır.

Singh, K., Saini, S. S., Yadav, S. K., Singh, H., \& Kumar, A. (2001). Effect of irrigation and row spacing on growth and yield of fieldpeas. Agriculturel Science Digest, 21(2), 127-128.

Singh, N. B. (2015). Alleviation of allelopathic stress of benzoic acid by indole acetic acid in Solanum lycopersicum. Scientia Horticulturae, 192, 211-217.

Spies, J. M., Warkentin, T., \& Shirtliffe, S. (2010). Basal branching in field pea cultivars and yield-density relationships. Canadian Journal of Plant Science, 90(5), 679-690.

Tan, M., \& Serin, Y. (1997). Kaba yem olarak kullanılan tahılların besleme değerine yaklaşımlar. Atatürk Üniversitesi Ziraat Fakültesi Dergisi, 28, 130-137.

Tan, M. ve Kadıoğlu, S. (2018). Erzurum şartlarında farklı tarihlerde kışlık ekilen yem bezelyesi çeşitlerinin verim ve bazı özellikleri. Tarla Bitkileri Merkez Araştırma Enstitüsü Dergisi, 27(1), 25-32.

Toğay, N., Togay, Y., Erman, M., \& Yıldırım, B. (2006). Kışlık iki bezelye hattı (Pisum sativum ssp. arvense L.)'nda farklı bitki sıklıklarının bazı tarımsal özellikler üzerine etkisi. Yüzüncü Yıl Üniversitesi Tarım Bilimleri Dergisi, 16(2), 97-103.

TÜiK. (2019). Bitkisel üretim istatistikleri. https://data.tuik.gov.tr/Kategori/GetKategori?p=Tarim-111. Erişim tarihi: 6 Aralık 2020.

Turgut, I., Duman, A., Bilgili, U., \& Acikgoz, E. (2005). Alternate row spacing and plant density effects on forage and dry matter yield of corn hybrids (Zea mays L.). Journal of Agronomy and Crop Science, 191(2), 146-151.

Uzun, A. (1997). Değişik yaprak formlarına sahip yem bezelyesi çeşitlerinde ekim zamanı ve ekim sıklı̆ının verim ve verim öğelerine etkileri. Doktora Tezi, Uludağ Üniversitesi, Fen Bilimleri Enstitüsü, Bursa.

Uzun, A., Gün, H., \& Açıkgöz, E. (2012). Farklı gelişme dönemlerinde biçilen bazı yem bezelyesi (Pisum sativum L.) çeşitlerinin ot, tohum ve ham protein verimlerinin belirlenmesi. Uludağ Üniversitesi Ziraat Fakültesi Dergisi, 26 (1), 27-38.

Weston, L. A., Harmon, R., \& Mueller, S. (1989). Allelopathic potential of sorghum-sudangrass hybrid (sudex). Journal of Chemical Ecology, 15(6), 1855-1865.

Yavuz, M. (2005). Üç farklı ekim sıklığında ekilen yem bezelyesi ve adi fiğde yatmanın ot ve tohum verimi ile kalitesine etkileri. Yüksek Lisans Tezi, Uludağ Üniversitesi, Fen Bilimleri Enstitüsü, Bursa.

Yavuz, T. (2017). Farklı biçim zamanlarının yem bezelyesi (Pisum sativum L.) ve yulaf (Avena sativa L.) karışımlarında ot verim ve kalitesi üzerine etkileri. Tarla Bitkileri Merkez Araştırma Enstitüsü Dergisi, 26(1), 67-74.

Yıldırım, S., \& Özaslan-Parlak, A. (2016). Tritikale ile bezelye, bakla ve fiğ karışım oranlarının belirlenerek yem verimi ve kalitesine etkileri. Çanakkale Onsekiz Mart Üniversitesi Ziraat Fakültesi Dergisi, 4(1), 77-83.

Yılmaz, Ş. (2008). Effects of increased phosphorus rates and plant densities on yield and yield-related traits of narbon vetch lines. Turkish Journal of Agriculture and Forestry, 32(1), 49-56. 